\title{
Economic Insecurity and Global Casualisation: Threat or Promise?
}

\author{
Guy Standing
}

Accepted: 18 October 2007/Published online: 6 November 2007

(C) Springer Science+Business Media B.V. 2007

\begin{abstract}
Casualisation has both negative and positive sides, for both workers and employers. This article considers how the positive sides could be developed while allowing casual work to continue to grow. In reviewing the advantages and disadvantages of casual labour for employers, the paper depicts casualisation (and the related process of 'informalisation') as usually involving seven forms of economic insecurity for the worker. The modern casualisation that is taking place as part of globalisation involves a steady restructuring of social income and labour recommodification, in which many workers are finding that an increasing share of their remuneration is coming from money wages, which are a relatively insecure part of their social income. As a result, there is a need to find new ways of providing income security that could allow workers to accept the more casual work arrangements without excessive anxiety and alienation. The article is, essentially, an argument for a re-assertion of a common sense of social solidarity, in which casual work can be a normal part of a flexible labour and work system.
\end{abstract}

Keywords Labour markets - Casualisation - Economic insecurity · Globalisation · Flexibility

\section{Introduction}

There is no doubt that the notion of "casual labour" throws up negative images. One thinks of the docklands (and black and white scenes from On the Waterfront), of workers waiting forlornly on corners for a day job of some kind, jostling for position with fellow

\footnotetext{
G. Standing

University of Bath, Bath, UK

G. Standing

Monash University, Melbourne, Australia

G. Standing $(\bowtie)$

20 chemin Champion, Collex 1239, Genève, Switzerland

e-mail: GuyStanding@standingnet.com
} 
supplicants. One thinks of women seamstresses waiting for some middle-man to come round with work from time to time, usually requiring some payment, in kind or in rental income, in return for being selected to receive a bundle to work into a product. And one thinks of workers without written contracts, employment security or the assurance of a steady reasonable income.

There is plenty to justify those images. Yet we must be careful not to be one-sided. The word casual is usually regarded as synonymous with informal. Think of the common use of casual wear, as opposed to formal attire. The image here is "you decide", a lack of standardisation, of imposed discipline, of control by somebody in authority. The downside of casual is unpredictability, being at someone's beck-and-call, insecure, dependent, patronised and so on.

This two-sided character is a warning to be careful about arguing that an increase in casual employment is an indicator of deteriorating labour markets. It might be, or it might not, even though we may be inclined to say it would. I am reminded of this for several reasons. Among them is that when, in a series of Worker Security Surveys, we asked about work satisfaction, a lot of people in casual employment expressed more satisfaction than many doing non-casual employment. And that way of putting it raises an additional concern. What is the opposite of casual? If casual is meant to be "bad", what is "good"?

My contention in this and related papers is that dignified work, the essence of Good Society, must be about being in control, and that a modern egalitarian should wish to achieve an equality of control and basic security. Before developing these points, it might be useful to reflect on the question: Casual on whose terms? If the casualness were at the whim of an employer, the worker would be insecure. If the worker were enabled to be as casual as he or she wished, it would be the employer suffering the insecurity. One might be amused by the prospect of the employer tearing his hair out at our non-appearance. But one could see the unfairness.

What this leads to is rethinking of the nature of employment contracts, and the evolving contractualisation of labour relations, which is a global phenomenon but which is probably most advanced in the USA.

The contextual argument is that the pressures of globalisation, via the flexibilisation and informalisation of labour markets, produce an agenda for casualisation. If certain favourable conditions applied, the positive side of casual could provide a happy outcome for favoured individuals or groups. But far more workers and families are facing the downside, which means extensive social and economic insecurity.

\section{What is Economic Security?}

Every serious social scientist adheres to some theory of distributive justice. And every such theory is based on a belief in the equality of something, be it income, wealth, opportunity or whatever. As argued elsewhere, the modern egalitarian should argue that, for full freedom, there must be an equal right to basic socio-economic security. This is a claim right, or republican right, in the sense that one should want policies and institutional changes to move society in the direction of realising it. (See Standing 2005).

What is required is universal basic security. If a person has no security, not only will she be vulnerable, but it would be unreasonable to expect her to adopt so-called socially responsible behaviour. Chronic insecurity induces adverse behavioural reactions. The modern Third Way paternalist would claim that a person should only be provided with security (social benefits) if they behaved responsibly. An egalitarian should retort that only 
Box 1 Types of economic security

Labour market security - Adequate income-earning opportunities; at the macro-level, this is epitomised by a government commitment to Full Employment;

Employment security - Protection against arbitrary dismissal, regulations on hiring and firing, imposition of costs on employers for failing to adhere to rules, etc.;

Job security-Ability and opportunity to retain a niche, an occupation or "career", plus barriers to skill dilution, and opportunities for 'upward' mobility in terms of status and income, etc.;

Work security-Protection against accidents and illness at work, through, e.g., safety and health regulations, limits on working time, unsociable hours, night work for women, etc., as well as compensation for mishaps;

Skill reproduction security-Good opportunity to gain and retain skills, through apprenticeships, employment training, etc., as well as opportunity to make use of competencies;

Income security-Assurance of an adequate and stable income, protection of income through, e.g., minimum wage machinery, wage indexation, comprehensive social security, progressive taxation to reduce inequality and to supplement those with low incomes, etc.;

Representation security-Possessing a collective voice in the labour market, through, e.g., independent trade unions, with a right to strike, etc.

if security were assured could responsible and solidaristic behaviour be expected. Basic security leads to more altruism and is instrumentally desirable, in that those who have security tend to be more tolerant and develop values of social solidarity.

To pre-empt a criticism, note that what is required is basic security, not unlimited security. If a person has too much security, indolence, opportunism and social irresponsibility easily follow. History is full of tales of the supine offspring of the idle rich, which is one reason why progressives have always argued that the inter-generational transfer of vast wealth is undesirable. By contrast, basic security leads to more rational decision-making and a greater sense of fraternité. And studies by psychologists show that people do not lose a sense of energy and innovativeness if they have basic security; they are more inclined to work in order to better their condition, as Adam Smith put it, and are more entrepreneurial.

Basic socio-economic security would arise if individuals and communities had assured access to their basic needs (food, healthcare, education, housing, etc.) coupled with protection in seven forms of work-related security (see Box 1).

For reasons given elsewhere, the vital forms are income security and representation, or voice, security. (See Standing 2002; ILO 2004). If a person had basic income security, he could make choices in freedom. But without representation or Voice he would remain vulnerable to losing that income security. The one without the other would be inadequate.

During much of the 20th century, the social democrats who set the political agenda advanced a model of labour-based security. Like most models, it contained structural inequalities, notably in its treatment of women and their work. ${ }^{1}$ Underlying the model was an uneasy social compact in which, in return for bearing the risks, the owners of capital received a disproportionate share of the economic surplus and retained the right to manage, while workers were provided with labour-related securities.

The era of welfare state capitalism-the pre-globalisation era-saw the advance of all seven forms of labour security, linked to performance of labour or the willingness to perform it. Primacy was given to labour market security, particularly between 1945 and about 1975, when Keynesianism was unquestioned by mainstream policymakers. For

${ }^{1}$ It ill-becomes ageing male academics to refer glowingly to a "golden age" back in the 1960s. It was blatantly sexist. 
situating casual labour, a key point was the presumption that most men would leave school as teenagers, enter and remain in stable unionised full-time employment until they left to spend a short period of retirement, supported by a modest pension and transfers from their offspring.

Meanwhile, women would be family dependents, sporadically acting as secondary wage workers while doing a lot of "housework". Social security was designed to provide compensation for contingency risks incurred in labouring. Governments, through acceptance of international labour standards, took labour out of international competition, which was essential to enable the gradual shift to state and enterprise benefits.

Part of the social arrangement was employment security, which applied mainly to men in core working-class jobs. The process can be depicted in Polanyian terms as labour decommodification, in which de-casualisation was a part. But it was an inegalitarian decasualisation, in that men in working-class families were provided with stability by having the core jobs. As female labour force participation rates rose, and as more women became attached to the labour market, they too obtained more employment security. But it remained a dualistic model, in which company men and secondary women workers were regarded as norms.

A related way of depicting what happened, and to assess what is happening in the globalisation era, is to break down the composition of the income compensation into the elements of social income. Basically, although many of the elements might be non-existent, any individual in any society has up to six sources of income, which together constitute his or her social income. This may be defined as follows:

$$
\mathrm{SI}=\mathrm{SP}+\mathrm{W}+\mathrm{CB}+\mathrm{EB}+\mathrm{SB}+\mathrm{PB}
$$

where SI is the individual's total social income, SP is self-production (whether selfconsumed, bartered or sold), $\mathrm{W}$ is the money wage or income received from work, CB is the value of benefits or support provided by the family, kin or local community, EB is the amount of benefits provided by the enterprise in which the person might be working, SB is the value of state benefits, in terms of insurance or other transfers, including subsidies paid directly to workers or through firms to them, and the value of social services, and PB is private income, gained through investment and private insurance.

The composition of Social Income can be further disaggregated as follows:

$$
\mathrm{SI}=\mathrm{SP}+\left(\mathrm{W}_{\mathrm{b}}+\mathrm{W}_{\mathrm{f}}\right)+(\mathrm{FT}+\mathrm{LT})+(\mathrm{NWB}+\mathrm{IB})+(\mathrm{C}+\mathrm{IS}+\mathrm{D})+\mathrm{PB}
$$

where $\mathrm{W}_{\mathrm{b}}$ is the base or fixed wage, $\mathrm{W}_{\mathrm{f}}$ is the flexible part of the wage (bonuses, etc.), FT are family transfers, LT are local community transfers, including income from charity, non-governmental organisations, etc., NWB are non-wage benefits provided by firms, IB are contingency, insurance-type benefits provided by firms to their workers, $\mathrm{C}$ are universal state benefits (citizenship rights), IS are insurance-based income transfers from the state in case of contingency needs, and D are discretionary, means-tested transfers from the state.

The relevance of the decomposition is that the prevailing pattern of remuneration indicates the degree to which a person is subject to labour market forces. Thus, one can assess the degree to which a person's labour is commodified and the extent to which he or she is commodified. To give the simplest example, if W were a very large share of SI, commodification would be greater than if $\mathrm{W}$ were zero or a small part of it. In a decommodification era, W would shrink as a share of SI, and SB would grow, whereas in an era of (re-)commodification W would grow. One would also expect that in the latter the more secure elements of SI would be eroded, due to institutional interventions or 
legislation, whereas those that were insecure or conditional on the performance of labour could be expected to grow in relative terms.

\section{Global Recommodification}

Since about the mid-1970s, there has been extensive labour re-commodification, in which (re-)casualisation has been one means of leveraging a new set of social relations of production and distribution. In the name of competitiveness, social scientists and policymakers are seeking to make labour markets more "flexible".

It is beggar-my-neighbour flexibility, since country after country is urged to make its labour system more flexible by reference to the apparently more flexible system somewhere else. Epitomising this, a debate is taking place in India about the need to make its labour market more flexible to be more competitive with China, the USA and elsewhere, at a time when the Indian economy is growing at $8 \%$ a year.

In general, but particularly in western Europe, one alleged cause of unemployment, slow economic growth and labour market "rigidities" is the employment protection system built up in the pre-globalisation era. Accordingly, country after country has weakened it. This is not labour market de-regulation, but re-regulation, in favour of employers relative to workers, the reverse of what had occurred in the post-1945 era.

Rolling back employment protection is part of a process of re-casualisation, as is the restructuring of social income taking place, which is intensifying income insecurity. It is the essence of labour re-commodification. There has been a shift back to $\mathrm{W}$, money wages, and a whittling away of entitlement to enterprise benefits, EB, and to state benefits, SB. Even within each of those, entitlement to non-wage benefits and forms of security is becoming more diversified or unequal according to work status.

If there is a shift to $\mathrm{W}$ and to PB (individualised benefits, as in savings accounts), it has historical resonance with the casual labour era of proletarianisation, memorably analysed by the likes of E.P.Thompson and Eric Hobsbawm. But remnants of the 'pre-capitalist' era have been swept away, leaving those being casualised and made dependent on money wages vulnerable and ready to indulge in concession bargaining as they surrender entitlements acquired by working-class struggles in the 19th and 20th centuries.

As the shift to $\mathrm{W}$ takes place, labour insecurity intensifies. In the globalisation era, fewer workers are covered by entitlement to what most in Canada would regard as the norm. If a worker falls ill, she cannot look to the employer. If she loses a job, it is less likely that an unemployment benefit awaits, and so on. What is emerging is systemic insecurity in this global transformation. (See Standing 2007). Whereas in the pre-globalisation era, there was a rough social compact in industrialised countries whereby capital took the risks and bore the insecurity, while being rewarded with higher income, now workers are enjoined to enjoy being active individuals in the risk society, facing the insecurities as a matter of personal responsibility.

This leads to a crucial part of the transformation. The class structure has fragmented into what can be called the globalisation class structure. We cannot analyse casualistion without coming to terms with the new classes and forms of social and economic stratification. Although the subject is more complex than can be painted here, we need to identify groups with distinctive sets of entitlements and patterns of security, since each will have distinctive attitudes to forms of social protection and commodification.

A feature of the fragmentation is that growing numbers of people are detaching themselves, or being detached from, national regulatory and protective systems. The 
fragmentation is accentuating seven distinctive strata, which can be presented in descending order based on average social income:

\subsection{The Elite}

At the zenith of the globalising economy is a tiny minority of absurdly rich and highearning people, whose impact is out of all proportion to their number. Some of these have reached the stage of seeing their incomes rising almost exponentially. They are global citizens. Expanding the stratum down to multi-millionaires, all are detached from national regulatory and social security systems, not needing or contributing to them, neither psychologically_not feeling committed to their maintenance-nor politically. The elite has strong income security, and whatever they need of other forms of security. Their biggest danger is hubris, and being caught in criminality.

\subsection{Proficians}

These are the new craftsmen of the global flexible economy. As the proposed name implies, they are a mix of professional and technician, mostly working as consultants or in short-term contracts. They operate in a climate of insecurity, but are well compensated. Perhaps their main form of insecurity is work insecurity, epitomised by the frenzied pace of their erratic schedules, stress and burn-out. Often able to evade or avoid taxation, they are at least partially detached from state-based social protection systems. Many are commodified in that they sell themselves with bravado. Confidence tricks are part of their trade. They glorify market society, until they burn out. Proficians comprise one group of casual workers. They tend to be detached from labour law protection, in that they are easily categorized as providing entrepreneurial services.

\subsection{The Salariat}

This consists of salaried employees, including those working in civil services, corporations, para-statials and other bureaucracies. They are the least subject to casualisation. They have employment security, but probably suffer from job and skill reproduction insecurity because they may be moved around and/or gain promotion in their enterprises only by leaving technical skills behind them. Because of their high incomes and a tendency to identify with management, with employers and with the elite and profician strata, members of the salariat typically feel detached from the state social protection system, seeing their future security in terms of private insurance benefits and earnings from judicious investment. They are still relatively protected from commodification and only suffer casualisation if marginalized within their stratum.

\subsection{Core Workers}

These comprise what those with long memories used to call the working class. Welfare states were created to serve their needs, those in full-time, regular, typically unionised jobs, with manual skills. During the pre-globalisation era, it was presumed that they represented 
the norm and that most workers in all countries would eventually belong to this stratum. The larger the proportion of workers belonging to the core stratum, the more people would be in a position to support and benefit from an insurance-based social protection system and the mainstream regulatory system.

Although the legitimacy of welfare states depended on them, core workers never comprised a majority in most countries, and since the 1970s have been shrinking. This is a reflection of "de-industrialisation", the dispersion of manufacturing labour around the world, and the pursuit of labour market flexibility. Core workers had most forms of labour security, but as the wage system has become more flexible a growing share of their income has been insecure. They also suffer from increasing job and employment insecurity, while their unions have been enfeebled. With numbers dwindling, and not expected to grow, their agenda lacks legitimacy. They have experienced more recommodification than any other group and more casualisation.

\subsection{Flexiworkers}

These comprise a disparate group in non-regular work statuses, including all forms of casual worker, outworkers and agency workers. Their common characteristic is labour insecurity in all forms. In the pre-globalisation era, it was presumed these "informal" statuses would decline as economies developed. Recently, they have appeared to be the future. Not only have the number trapped in petty activities in rural and peri-urban areas grown, but flexible labour processes have boosted other forms. Growing proportions of labour forces lack entitlement to mainstream statutory protection and are disentitled to social transfers.

\subsection{The Unemployed}

Globally, the number has risen in this era, although the distribution of the unemployed has shifted, and more are unmeasured. They suffer growing labour market insecurity, and income insecurity, because unemployment benefits have been cut, duration of entitlement has been shortened, and conditions for entitlement have been tightened, while a form of contractualisation (discussed later) is turning their status into something closer to labourin-unemployment.

\subsection{The Detached}

This is a growing category, cut off from mainstream state benefits, lingering in poverty, anomic and threatening those above them in the income spectrum. Politicians have been inclined to treat these victims of economic liberalisation as in need of "re-integration". They linger in the streets, in bus and train stations, in city parks. They make those above them in the social order feel uncomfortable or smug, depending on where they fit. The detached represent fear. And it is fear that induces concessions from the near poor-the ultimate tool of inequality and casualisation.

If one divides societies and the international economy into these seven strata, one sees that the top three are increasingly detaching themselves from state-based social protection, 
while the bottom three are being detached by explicit and implicit disentitlement to its benefits and services. Although one may choose a different way of presenting the stratification, the analytical device may also help us to picture the growing inequality of social income and the widespread deterioration of economic security.

Table 1 is an interpretation of what anecdotal evidence suggests are the sources of income received by the strata, or the sources on which each mainly rely. The asterisks indicate the main sources for the higher-income strata (with three asterisks indicating that this is huge and growing, with $\mathrm{K}$ indicating capital income); a blank implies that the source is not applicable, or that no guess on aggregate trend is reasonable. The table's final row indicates what seems to be the global trend for the source of income specified by the column. Thus, the base wage has tended to decline as a part of social income, the flexible part of the wage has been rising, income from private savings and investment has been rising, and so on. The \pm sign indicates the direction of change of the sources of social income for particular groups.

Table 2 complements Table 1, in that it indicates how the seven strata experience various forms of security, a plus sign indicating relatively strong security, a negative sign a relatively weak situation. Thus, for example, proficians have high levels of income security and skill reproduction security, being in control of their own activities, but no employment security. Their income security enables them to cope with their voluntary casualisation. Core workers have some employment security (although diminishing), relatively high work security and reasonable entitlement to enterprise and other benefits.

Table 1 Sources of social income, by socio-economic status

\begin{tabular}{|c|c|c|c|c|c|c|c|c|c|c|}
\hline Sources stratum & $\mathrm{W}_{\mathrm{b}}$ & $\mathrm{W}_{\mathrm{f}}$ & FT & LT & NWB & IB & $\mathrm{C}$ & Is & $\mathrm{D}$ & $\mathrm{PB} / \mathrm{K}$ \\
\hline Elite & & & & & & & & & & $* * *$ \\
\hline Proficians & & $*$ & & & & + & + & & & $*$ \\
\hline Salariat & $*$ & + & & & $*$ & $*$ & + & + & & + \\
\hline Core & + & + & & & + & - & - & + & & \\
\hline Flexiworkers & - & + & + & + & & - & - & - & & \\
\hline Unemployed & & & + & + & & & - & - & + & \\
\hline Detached & & & & + & & & - & & + & \\
\hline Global trend & - & + & & + & \pm & \pm & - & - & + & + \\
\hline
\end{tabular}

Table 2 Forms of labour security, by socio-economic status

\begin{tabular}{|c|c|c|c|c|c|c|c|c|}
\hline $\begin{array}{l}\text { Security } \\
\text { stratum }\end{array}$ & $\begin{array}{l}\text { Labour } \\
\text { market }\end{array}$ & Employment & Job & Work & $\begin{array}{l}\text { Skill } \\
\text { Reprod. }\end{array}$ & Income & Benefits & Representation \\
\hline Elite & + & + & + & + & + & + & + & 0 \\
\hline Proficians & $(+)$ & - & - & - & + & + & 0 & - \\
\hline Salariat & + & + & $(+)$ & + & $(+)$ & + & + & 0 \\
\hline Core & 0 & $(+)$ & 0 & + & 0 & 0 & + & + \\
\hline Flexiworkers & - & - & - & - & - & - & - & - \\
\hline Unemployed & - & - & - & - & - & - & - & - \\
\hline Detached & - & - & - & - & - & - & - & - \\
\hline
\end{tabular}

Note: + , above average; 0 , average or not applicable; - , below average 
Taken together, Tables 1 and 2 suggest a way of interpreting what is happening to incomes and income security. The class fragmentation produces a situation in which the top three strata feel increasingly detached from the mainstream state social protection system. They are thus less inclined to defend its principles of social solidarity, while the bottom three strata feel deprived, detached by disentitlement to the benefits long offered to core workers, to whose ranks they had aspired. To them, there is no solidarity on offer, and to talk about social solidarity would sound like a sick joke. The detachment and lack of social solidarity have contributed to the loss of legitimation of the welfare state.

This leads to another awkward aspect of casualisation. Traditionally, the great crafts and professions have stood as barriers to commodification, and those entering them have obtained a range of securities and identities that are barriers to casualisation. But in every great transformation, the social and detailed divisions of labour advance. And what we are witnessing is the restructuring of occupations, or rather the proletarianisation of occupations. In this, small elites sub-divide the profession, generating a mass of more insecure subsidiaries subject to market forces to a much greater extent.

Instead of closed occupational labour markets, with entry followed by career progression, there is a splitting of the occupation, so that workers doing various sets of tasks are shut out of the opportunity to move up the ladder to somewhere near a pinnacle. Casualisation arises via loss of control over abstract knowledge and over entry into the community of the dominant profession or craft.

One could develop this theme considerably. However, the point is to emphasise that recommodification and re-casualisation are intimately linked, and are leveraged by the insecurities associated with the growing inequalities and class fragmentation.

\section{Casualisation, Contractualisation and Informalisation}

Globalisation, labour flexibility and re-commodification are associated with four closely related but distinctive trends. These are informalisation, casualisation, contractualisation and, least considered, occupational commodification.

Informalisation has taken three forms. The first predominates in most developing countries, and is a preoccupation of commentators in Latin America and South Asia. Basically, it consists of movement into petty production activities in the slums, into low productivity, low-income livelihoods to achieve survival. The second has, to some extent, been a response to the growth of the first, in that it consists of firms informalising their employment, by turning to the use of sub-contractors, outworkers and the like. The third refers to the use of illegal forms of labour, to avoid tax and social contributions and to achieve systematic evasion of regulatory safeguards.

All three forms of informalisation have spread to industrialised countries in the globalisation era. They have become almost the norm for labour relationships in eastern Europe since 1989. Black economy labour has become widespread. Often, the employer and worker split the difference, in that a slightly higher wage is paid because the employer is saving by not paying contributions or taxes. Such informal arrangements have spread into western Europe as migrants find their way there.

Casualisation is a more specific development. It refers to a shift from regular, quasipermanent employment to the use of workers in short-term employment arrangements. Two distinct trends are at play. One we may call explicit casualisation, the other implicit. The first is the one on which most comment is made, i.e., a shift of employees from regular to casual categories. 
The second is more invidious and more pervasive. It refers to the gradual weakening of the conditions that characterise regular employment, so that regular employment takes on the character of casual, in all but name. And one must beware of interpretating figures on employment tenure as evidence that there is limited casualisation. A trend from regular to casual work status does not necessarily mean that the average duration in employment will decline. It means that more people are working with insecure employment status.

As far as the growth of workers in casual work statuses is concerned, there does appear to be a considerable rise in numbers in some countries, including Canada. For example, in Australia the number and share of the labour force in casual work statuses has risen steadily for the past quarter of a century (Campbell and Brosnam 2005).

Of course, while some countries have a specific definition of 'casual', in practice there is a wide range of types, including "casual-casuals, regular-casuals and permanent-casuals", as found in New Zealand (Whatman et al. 1999). At the extreme are those with no employment contract of any kind, who have no security, no prospect of it, and are at the whim of an employer. Next are those who have a temporary contract, perhaps as short as a day at a time, perhaps as long as 6 months. In some cases, that may be understood to be renewable and to continue for a long time. More often than not, to ensure the worker does not qualify for benefits or other entitlements, the worker must accept a time limit and then have a break in employment, as occurs in various civil services and UN agencies.

Then there are workers who are classified as casual by virtue of the limited number of hours of work they are contracted to provide. They may be called "part-time" workers, and not be classified as casual, but that is what they are in reality. Some workers may be contracted for a limited number of hours, but informally be required to work longer, when needed.

A form of casual worker not described as such is the probationary worker. By being in a probationary status, the worker is typically denied a wide range of entitlements-including protection against arbitrary dismissal-and is usually paid on a lower wage scale. Employers, unless hindered by legislation or collective agreements, can alter the terms and conditions of probationary employment. This has been the practice in many countries, and extending probationary periods is a method of casualisation by stealth.

Another growing casual work status consists of those hired out to firms by employment agencies, the temps of the world. This is the most rapidly growing form of employment in industrialised countries. In effect, firms are contracting out their employment. In some cases, the worker is put in a casual work situation, but is employed by the agency on a longer-term contract. More often a person is casually hired by an agency and hired out to a firm, perhaps with a holding contract with the agency.

There has been a growth of sub-contracting, out-sourcing, use of shadow labour, use of illegal migrants on non-binding contracts, illegal tax-evasion labour, and the use of prison labour, which is the most casual form of labour, in that the worker has no rights, cannot bargain and can be given as much labour as somebody sees fit.

Not all these statuses are casual in every sense of the term, and some observers would be inclined to say that some should be excluded. However, all are casual in some senses, with some being more insecure in some respects, some in others. Their casualness stems from a lack of the forms of security mentioned earlier, particularly employment, job and income security. And they are subject to various forms of control to a greater extent than other workers, a reflection of their subordination and commodification.

In addition, there is casual work that is not labour. Some observers would object that this is putting too much into one basket. However, one of the worst failings of 20th century work and labour statistics was the deliberate exclusion of certain types of work from all 
classifications. The work disappeared as work. Foremost is care work, which is intrinsically casual in that there are no labour securities. A defining feature of care work is that, typically, the gift relationship dominates the commercial relationship.

A rising form of casual work is so-called civil society activity. Not all is casual, in that employment contracts are often involved. But a great deal of voluntary work and community work and work done for NGOs is casual, even if much of this work is becoming more contractual and regular.

Contractualisation refers to the global trend towards individualised labour contracts. The motives for this are complex. The employment relationship is always an incomplete contract, since workers can always adjust their effort bargain, and there is always a process of informal renegotiating as an employment relationship unfolds. What individualised contracts often attempt to do is to tighten the conditions to minimise the uncertainty for the employer and to maximise the capacity to impose penalties for abrogation of the terms of the labour agreement.

This may seem like de-casualisation. But to open the space for contractualisation, governments and employers have been whittling away at collectively bargained contracts. With those, the collective of workers is bargaining with firms or sectors, and the strength of bargaining power is relatively equal. When such mechanisms are dismantled, or where the scope of collective bargaining is reduced, there is the space for individualised contracts. This leads to an irony. For the shift to individualised contracts around the world (epitomised by China's Labour Law of 1994) will lead to fewer workers having formal contractual employment, for a while.

A new form of contractualisation is reaching the unemployed. This refers to the imposition of contracts for the unemployed, renamed clients as befits the therapeutic culture that guides so much social policy restructuring. Giving contracts to the unemployed is part of the redefinition of the social democratic welfare state, extending labourism in a way scarcely envisaged by early generations of social democrats. ${ }^{2}$

Contracts for the unemployed are instruments of re-commodification, to increase efficiency and re-integration rather than to provide economic security and liberation from market forces. Where social insurance at least had the notion of compensation for labour market risks, this removes any idea of an insurance contract.

A question raised by this trend is whether employment contractualisation leads to more or less "dependency" on the state? Reformers leading this transformation state that the objective is to reduce dependency. But anybody studying what the social workers are doing could only be impressed by the state paternalism involved, turning the unemployed from citizens needing security and compensation for their unemployment into clients who are objects for restructuring and improvement, objects with obligations.

\section{Casualisation for Employers: The Pros and Cons}

We have grown tired of hearing how employers need flexibility in their labour relations. It is a euphemism for control. But this does not mean they want complete casualisation. What they want is to be able to make changes as and when they see fit, without objection. Fortunately, enough of them realise that it is bad to have everything you think you want.

\footnotetext{
2 This form of contractualisation has begun to receive attention from social scientists, led by labour lawyers. See Sol and Westerveld (2005).
} 
The supposed benefits are well known. Those on casual status usually receive lower wages, although in places like Australia and New Zealand there has traditionally been casual loading pay of up to $20 \%$ extra (although less so now). The cost benefit extends to avoidance of experience rating pay, as well as denied entitlement to a wide range of enterprise benefits. The benefit for employers extends to the ability to lay off or dismiss workers whenever there is a shortfall in orders or a fluctuation in labour to perform. This enables them to avoid fixed labour costs when there is little labour to do.

The most-noted benefit for employers is avoidance of non-wage labour costs, in the form of paid leave, sick leave, healthcare compensation and so on. In industrialised countries, these costs became huge in the era of fictitious labour decommodification before globalisation. Using casual status workers was a way of avoiding the EB costs, which became more important as international competitiveness forced firms to try to cut labour costs vis-à-vis those in other countries.

The primary indirect benefit for employers comes from the threat the presence of casual workers represents for regular workers. Not only are casual workers perceived as more amenable to real wage cuts, erosion of benefits, variations in working time and arbitrary penalties for errors, real or imagined. They are also likely to make other workers feel more resigned to such treatment themselves.

Another employer benefit, particularly for those eponymous small-scale businessmen much loved by liberals, is ideological comfort. The employer can go home comfortable in the reflection: "I am the boss. If they do not do what I tell them, or as I expect, then I can get rid of the blighters". This taste for casualised labour may dominate the economic rationality for or against use of casual workers. (See Smith and Ewer 1999).

There are potential downsides for employers, which have prevented wholesale casualisation and led mainstream employers to oppose it. Casualisation induces workers to lack commitment to the firms of their employment, and lowers productivity. This traditional argument has been given additional spice by the recent belief among management "scientists" that among the most important skills in the services accounting for most new jobs is emotional skill, which apparently is best harnessed to the needs of companies by employment that engenders feelings of loyalty and commitment.

Other downsides include a lack of skill acquisition, particularly those acquired from fellow workers. Casualisation tends to depress workplace innovations and makes workers not care for equipment or raw materials, resulting in higher non-labour costs. Employers and some policymakers also realise that workers who are relatively secure in their jobs are more likely to put pressure on management to improve working conditions and put pressure on management to improve efficiency in order to obtain decent profits.

\section{Casualisation as Threat-Flexiworkers}

For workers, what are the negative aspects of casualisation? Most of the downsides are well known. The upsides are rather more nuanced.

Besides the psychic cost of feeling unwanted on a long-term basis, the downsides obviously include employment insecurity, which translates into lower status as consumer and as citizen. Try obtaining a loan or mortgage when you have only a casual job. But the insecurity extends to all the forms outlined earlier. Casual workers usually have no entitlement to a wide range of enterprise benefits, most of which impart security. Casual workers also fail to obtain seniority and/or experience-rated pay. 
They also have a relatively low probability of entitlement to state benefits, which is less often appreciated by observers. Disentitlement is extensive, and has grown as social security has been reformed under the impact of globalisation and attempts to cut social spending, which has induced governments to lengthen contribution periods for entitlement, for example, and to privatise diverse state benefits and social services.

What is even less appreciated is that casual workers risk losing access to family-based benefits (FB in the social income). Giving support to relatives and friends is rarely entirely altruistic. It is usually based on implicit reciprocity, with the unstated understanding that someone in security today gives to someone without it in the expectation that when they themselves are in need they will be able to turn to today's recipient for help. The nature of the class re-stratification makes such reciprocity less likely; those who could be donors will be more reluctant to help those in casual jobs.

Casual workers also lose out in more direct ways. They have less access to training, and often have to pay to obtain it, unlike the situation for regular workers. And they have less reason to take training courses because they cannot expect to receive a return on the investment, especially if the skills are firm-specific or sector-specific.

Finally, casual workers are left exposed to various forms of harassment. Women are more susceptible to sexual harassment because they are vulnerable to employment loss and are thus more subject to pressures in return for the promise or expectation of employment renewal.

The upsides of casual status for workers are harder to identify. However, the effect on perceived autonomy should not be overlooked. Too many people admit late in life that they were trapped in a leaden cage by clinging to a long-term job that had rarely given them intrinsic satisfaction or joy. Casual workers may also be able to negotiate a more flexible schedule that accords to their needs or desires.

Another claimed benefit is that casual labour offers a route from unemployment into regular employment, a stepping stone in a process of assimilation. While this may be so for many people, it may result in a person building up a profile of instability, through a series of rolled-over short-term contracts that imparts an image to potential employers of behavioural instability.

Another benefit claimed for casual work is that it suits the needs of many people. With a rising incidence of youth in tertiary schooling, more people aged 16 to about 25 want only casual jobs, and may be able to pay for their schooling by a series of them. Similarly, many young women contemplating having children, or having them, may be inclined to want occasional, casual jobs, although there should be no presumption that they should be expected to take such jobs. Even more significantly in the 21 st century is the vast number of older workers, who have left some career job or are ready to do so, wanting a casual work activity, whether to boost an inadequate pension or to keep themselves active and socially involved.

Recognising the positive aspects leads to the peculiar position of the emerging category we have called proficians.

\section{Casualisation as Promise-Proficians}

Casual work is the life of proficians. In most respects, their life is to be envied rather than pitied. Consider all those consultants. To give a recent set of examples, in 2005 the UK Government's bill for consultants was more than $£ 2.2$ billion (The Guardian, September 2, 2006:1). The consultants typically earned three times as much as regular 
employees doing similar work alongside them, and in several government departments the bill for consultants was much more than the wage bill for all salaried staff. One section of the Department of Health had almost as many consultants as full-time officials. Meanwhile, it has been estimated that private enterprises spend proportionately much more on consultancies, and spend between $3 \%$ and 5\% of their annual expenditure just on management consultants, according to the Management Consultants Association.

Clearly, casual work is good if you can obtain it in this realm of the labour market. But this does not mean it does not make sense for both the employers and the proficians to continue this practice. Productivity may be higher; overhead costs may be lower; labour relations may be smoother. The proficians are growing in number and may continue to grow to account for more than $10 \%$ of total income-earners in post-industrial societies. A challenge for policymakers, agencies and civil society bodies is to turn more of the flexiworkers into something closer to the proficians.

For that to happen, more people must have basic economic security and be able to develop their capabilities into bundles of portable skills. For that to happen, the educational system and employment services need to be transformed. Both are taking place slowly. To ensure that they do so efficiently and equitably, policymakers need to consider both the positive and negative sides of casualisation.

\section{Policy Options for Responding to Casualisation}

Casualisation could be good for you. Usually, it is not. Informalisation could also be good; usually it is not. In both cases, to move towards acceptability requires the establishment of a floor of universal social and economic rights. The collective bargaining regime of the 20 th century at least entailed a government commitment to minimum substantive standards for all workers. This was sexist and sharpened distinctions between those outside the labour market and those in the standard employment relationship. But the current "employment rights" regime, with a plethora of judicial rules coupled with "human resource management" (HRM) techniques is sharpening divisions between those in different forms of work status. A result is that labour law is becoming more of an instrument of division. Labour law protects some people and not others. Those others are becoming more common.

In those circumstances, there are two possible routes to labour law reform. One is to extend coverage to non-standard forms of employment. This tends to mean those near the standard. As such, it offends equity principles, since the worst affected are those not close to the standard. This does not mean that this route should be abandoned, but it does require more attention to labour inspection and the expansion of agencies to give protection and information to disadvantaged workers. The second route is more promising, and is essential. This is to build a core or floor of basic economic rights for all workers doing all types of work.

Casual work would be acceptable, even desirable if the degree of casualisation could be bargained between equal parties and in which the worker had basic economic security. Recall that this requires the two meta forms of security-Income and Representation. If a person had an assured basic income and assured Voice, collective and individual, then casualisation could be a route to a dignified and satisfying way of living. This should be our main message. 


\section{Appendix: A Road to Re-casualisation}

What is euphemistically called "the international community" has promoted (re-)casualisation. Spokespersons for the World Bank, IMF and OECD would not put it like that. They would call it "labour market flexibility". But the claim is not hyperbole. Pressure is placed on governments, by employers and their lobbyists and by international agencies, to roll back protective legislation and regulations, or not to introduce them, ostensibly in the interest of employment generation and national "competitiveness".

By this means, policymakers can rationalise making it easier to dismiss workers and less costly to do so, narrowing the difference between regular and casual, lessening the need or incentive for employers to resort to casual labour. One could even have an increase in casualisation at the same time as there was a reduced incidence of workers in casual statuses.

All countries are being monitored, and this is not an innocent sport. Consider just one way by which casualisation is being promoted. The World Bank, drawing inspiration from OECD research, has constructed a Rigidity of Employment Index, by which it ranks countries. Let us presume it did not calculate this index just for amusement, but rather intends it to be used in its lending operations, for putting pressure on governments to change their policies, and as a guide to firms contemplating investment decisions (which is why the results are presented in the Bank's "Doing Business" website). Let us also presume that the words chosen by the Bank are not random, so that "rigidity" refers to objects that should be cut. It follows that a country with a high Rigidity Index score must be "bad".

Then turn to how the index of badness is created. It turns out to be a castle of indicators. It is worth highlighting some of the key building blocks, since they relate to some of the main elements of casualisation. High scores on any component of the index is "bad" (rigidity), low scores are "good" (flexibility).

The Employment Rigidity Index is computed as the sum of a "difficulty of hiring index", "a rigidity of hours index" and a "difficulty of firing index", divided by three. Among indicators used in the hiring difficulty index is "whether term contracts can be used only for temporary tasks". If yes, that is bad. If a country has a restriction on the duration of short-term contracts of $<5$ years, it fits in the bad boy column, whereas if it allows a series of short-term contracts for longer, it is good.

The component indicators of "rigidity of hours" are tendentious, giving good (low) scores for countries that favour employer freedom, bad scores for those regulating working hours and providing leave. The "difficulty of firing" index is more relevant to casualisation, and has eight components. To give a flavour of the process, if employers are obliged to "notify" a government agency that they are "terminating workers" (sic), that is a mark up for badness (or "difficulty", which cannot mean good). If the law requires a company to obtain "approval from a third party to terminate one redundant worker", that is regarded as doubly bad (i.e., given a weight of two in the index).

Some countries do remarkably badly in the resultant Rigidity of Employment Index. I hesitate to name and shame. But African countries are particularly "bad". Whereas the USA is a model of goodness, scoring 0 (very, very good; cannot be better) and Canada should be filled with pride, scoring 4 (very good; room for improvement), Angola scores a shocking 64, the Central African Republic a scandalous 73, South Africa scores 43.

Before you rush out to demand that these countries should de-rigidify, look at the small print in this charter for casualisation. The indicators are calculated on the basis of a long list of "assumptions about the worker", as well as "assumptions about the business". In 
other words, the estimates are based on a selected type of worker, not all workers or even some notion of average worker. Thus, the "difficulty of firing index" refers only to those workers who are, inter alia, (1) men, (2) full-time, (3) in regular employment, (4) employed "in the same company for 20 years", and (5) earning a "salary plus benefits equal to the country's average wage during the entire period of his employment".

I would give my Index of Certainty a score of 0.99 that there are few Angolans who would qualify. If right, the rigidity index is a sham. This would not matter much if it were not being used to persuade governments to reduce safeguards against casualisation. But New York Credit Rating Agencies are probably using the index in their country ratings, while consultants are advising multinationals on the cost of "doing business" in various countries.

The message is simple: Roll back those barriers to casualisation! I am inclined to be sceptical. We have been doing fieldwork in Mozambique, and most people there are in statuses that analysts would describe as "casual" by any standard imaginable in Canada or the USA. The World Bank's index of employment rigidity for Mozambique is 54.

This would be amusing, were it not for the uses to which such measures are put.

\section{References}

Campbell, I., \& Brosnam, P. (2005). Relative advantages: Casual employment and casualisation in Australia and New Zealand. Paper presented at workshop on globalization and industrial relations reform in Australia and New Zealand, Sydney, February.

ILO. (2004). Economic security for a better World. Geneva: ILO.

Smith, M., \& Ewer, P. (1999). Choice and coercion: Women's experiences of casual work. Sydney: Evatt Foundation.

Sol, E., \& Westerveld, M. (Eds.). (2005) Contractualisation in employment services: A new form of welfare state governance. Amsterdam: University of Amsterdam, Kluwer Law International.

Standing, G. (2002). Beyond the new paternalism: Basic security as equality. London: Verso.

Standing, G. (2005). About time: Basic income security as a right. In G. Standing (Ed.), Promoting income security as a right: Europe and North America. London: Anthem Press.

Standing, G. (2007). Labour re-commodification in the new transformation. In A. Bugra (Ed.), Re-reading Polanyi in the 21st century. Harmondsworth: Palgrave-Macmillan.

Whatman, R., Harvey, O., \& Hill, R. (1999). The effects of employment regulation: Case study research in the accommodation, winemaking and brewing industries. Wellington, New Zealand, Department of Labour, Occasional Paper. 